\title{
IDENTIFYING THE CRITICAL CAUSES OF CONFLICT IN CONSTRUCTION PROJECTS IN NIGERIA
}

\author{
0. A. Ejohwomu ${ }^{1}$, O. S. Oshodi ${ }^{2}$ and M. K. Onifade ${ }^{3, *}$ \\ 1, 3 Department of Management Technology, Bells University of Technology, Ota, Ogun State. NiGERIA

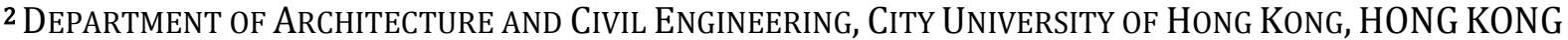 \\ E-mail addresses:1 obuksejohwomu@yahoo.co.uk,2ososhodi2-c@my.cityu.edu.hk, \\ 3 morakinyo.onifade@yahoo.com
}

\begin{abstract}
Completing construction projects entails inputs from various professional disciplines; this makes projects prone to conflicts. It has been acknowledged that management of conflict is crucial to improving project performance. Thus, understanding the causes of conflicts in construction project will ease the process of conflict management. This study sets out to gain an in depth understanding of the causes of conflicts in Nigeria using mixed method research approach. Both questionnaire survey and interview were used to capture the perspective of consultants and contractors on causes of conflicts. Based on the responses, it was evident that poor financial projection on the client's side is the most significant cause of conflicts. Furthermore, it was found that there are no differences in the perception of both groups of respondents. This finding was also evident from interviews. Thus, there is a need for clients to develop procedures of engaging competent and experienced consultants so as to reduce the likelihood of conflicts.
\end{abstract}

Keywords: construction projects, conflict, mixed method, Nigeria

\section{INTRODUCTION}

Construction projects have four distinct but interrelated phases- briefing, design, construction and post-construction. The completion of these phases requires the professional services of several disciplines within the built environment. The multiplicity of disciplines involve in construction projects has been linked to conflicts, which evolve due to differences in interest, concerns, training, and perception [1]. Commentators in the field of construction management have also attributed occurrence of conflicts in construction projects to adversarial relationships, multi-disciplinary nature and differences in interest of project participants [2][4]. It is evident that human interactions during these phases yield conflict which affects project outcomes.

There is a general consensus that conflict leads to dysfunctional project outcomes. This is supported by evidence which showed that the quality of relationship amongst project team members and project outcomes is positively related [5]. Other similar studies have shown that low productivity, low morale, distrust, communication problems, requirement instability, rework and disputes are outcomes of conflicts [5], [6].However, Awakul and Ogunlana [7] contend that there is a need to keep conflict within allowable limits in order to produce functional project outcomes. The term 'functional project outcomes' can be viewed as improved decision making, trust, team creativity, stakeholder satisfaction and group performance [8], [9]. In addition, Awakul and Ogunlana [7] report that the causes of conflicts and its classification dictates its management. Therefore, conflict and conflict management play a crucial role in project outcomes.

In construction management literature, authors have classified conflicts based on several criteria. The criteria used in literature are: origin of conflict [7] and project phase [10].Conflicts can be classified into internal and interface conflicts. Internal conflicts are viewed as conflict within project team; however, interface conflicts are conflicts between project team and external parties [7]. A similar classification was presented in Dada [11], although, it is worthy to note 
that the term "interface" was used as "external". In contrast, conflict was classified based on project phase into three classes namely: planning, design and construction [10]. It is imperative to note that Mahalingam and Levitt's classifications overlap; this is because a particular type of conflict can occur in two classifications. Therefore, classification of conflicts based on origin is preferred due to non-overlap. Thus, Awakul and Ogunlana [7] classification was adopted for this study.

There is a need to understand the Awakul and Ogunlana [7] classification of conflicts in construction projects. Awakul and Ogunlana [7] describes conflicts that arise within project teams as internal conflict. However, conflict between project team members and any individual not part of the project team is classed as external conflict. In construction-related research, Consoli [12] studied conflicts in Australian private prison projects using a qualitative approach. It was found that personality clash amongst project participant, choice of procurement method, and relationship amongst project participant were major causes of conflicts. However, Acharya et al. [1] studied causes of conflicts in Korean construction projects and argued that differing site condition, public interruption and differences in change order evaluation were responsible for conflicts. It is evident that these findings tend to vary with sample characteristics.

A considerable amount of literature has been published in construction management literature focused on conflicts. For instance, causes of conflicts have been studied in Hong Kong [4, 13]; Thailand [7]; Korea [1]; Nigeria [11, 14]; and Tanzania [15]. In the Nigerian context, Dada [11] study was focused on internal conflicts in two construction project procurement approaches - traditional and integrated (i.e. design and construction phase is handled by one organization). It was found that integrated approach is more adversarial than the traditional approach. Oshodi and Ejohwomu [14] presented the preliminary results of a study on conflicts in construction projects in Nigeria. It was found that client's poor financial projection is a major cause of conflicts. It is imperative to note that small sample size was a limitation to this earlier study. Thus, this study sets out to investigate the critical causes of conflicts in construction projects in Nigeria using a mixed method research approach. Where mixed refers to all procedures collecting and analyzing both quantitative and qualitative data. An approach that expands the scope or breadth of research investigation. The study set out to identify the threshold of positive conflicts in project delivery in Nigeria through the lens of two project stakeholders (consultants and contractors).

\section{THE CONCEPT OF CONFLICT, CLAIM AND DISPUTES}

The term "conflict" has been operationalized in several contexts in construction management literature. Often, the term "conflict", "claim" and "dispute" are used interchangeably. However, authors such as Acharya et al. [1] have delineated (Figure 1) the differences in the terms "conflict", "claim" and "dispute".

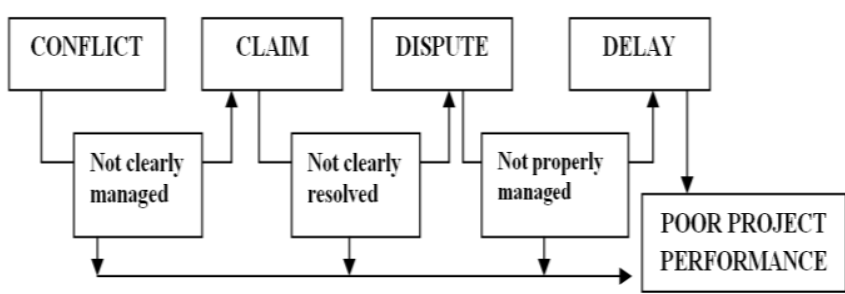

Figure 1: Conflict, claim, dispute and delay continuum model, Source: Adapted from Acharya, et al. [1]

Because there is no generally accepted definition of "conflict" in construction literature, there is a need to identify key words used to qualify the term in order to fully understand it. According to Tjosvold [16], conflicts are incompatible activities amongst team members, where the actions of one member tend to interfere and obstruct the actions of another. Acharya et al. [10 asserts that conflicts within project teams arise due to divergence in interest amongst team members. Similarly, Lester [17] asserts that conflicts result from differences in aspirations, attitudes, views, opinion and interest amongst project teams. From these views presented by different authors, it is evident that lack of co-ordination amongst project teams which results from non-convergence of ideas, opinions, interest and training can be termed as "conflict". Conflicts are critical components of project lifecycle which arose due to human interactions and its management is paramount for project success. Therefore, there is a need to understand the causes of conflicts as so to improve its management.

\subsection{Causes of Conflicts in Construction Projects}

Several studies have identified causes of conflicts in projects. Early studies such as Wilemon cited in Kerzner [18] identified causes of conflicts to include: diversity in expertise of project participant, project 
manager's low level of authority, undefined project goals, undefined roles among project teams, undefined project priorities, fear to losing relevance among project team due to implementation of project management, and undefined channel of communication. In a similar vein, Williamson [19] categorised causes of conflicts into three classes namely behavioural; contractual; and technical problems which arise due to uncertainty. In recent studies, there have been an increased number of causes of conflicts and this is due to changes in project size, environment, complexity and requirement.

\section{RESEARCH STRATEGY}

In order to achieve study's objective, a combination of literature search and questionnaire survey was used. The questionnaire survey was used due to its convenience when gathering information from a large number of respondents. In addition, interviews of four construction industry experts was used to corroborate the findings obtained from the field survey. A convergent mixed method designed was adopted [20]. The use of multiplicity of methods ensure that both methods complement each other (i.e. in terms of strengths and weakness). A questionnaire was developed to study the relative importance of the causes of conflicts in construction projects in Nigeria. This is similar to the method in Acharya et al. [1] and Ntiyakunze [15] with incorporation of a 5-point Likert scale ( 1 is very low, 2 is low, 3 is moderate, 4 is high, 5 is very high) for measurement purposes. Concurrently, qualitative data was collected from purposively selected interviewees.

A pilot study was conducted prior to the initial preliminary study [21]. This was done to validate the questionnaire developed. This led to the addition of the variable "Local Trade and industry" as a cause of conflict. To ensure the usefulness and reliability of the survey findings, samples of respondents were randomly selected. Unlike previous studies, such as Acharya, et al. [1] and Ntiyakunze [15] which covered the perception of clients, consultants and contractors. Client's response is not part of this study; this is because most clients (except large corporations) do not have construction professionals as employees and most projects are one-off endeavour. Hence, clients usually engage the services of consultant to act as their agents.

A total of 300 questionnaires were distributed to subjects in the construction field. Out of the 300 questionnaires sent, 91 numbers of usable responses were received, which represents a 30.33 percent response rate. Such a response is not uncommon with survey [20] and is regarded as acceptable based on the findings of Akintoye [22]. Table 1 summarizes the profiles of the respondents, with 53 (58.2\%) respondents being from contractors and 38 (41.8\%) from consultant groups. $76.9 \%$ of the respondents had more than 5 years of experience in the Nigerian construction industry and large percentage of respondents were reasonably qualified academically. Thus, this suggests that the respondents of the survey are relatively qualified and experienced.

Table 1: Characteristics of respondents

\begin{tabular}{lccc}
\hline & $\begin{array}{c}\text { Consultant } \\
\%\end{array}$ & $\begin{array}{c}\text { Contractor } \\
\%\end{array}$ & $\begin{array}{c}\text { Overall } \\
\%\end{array}$ \\
\hline Educational training & & & \\
Project manager & 9.9 & 15.4 & 25.3 \\
Architect & 9.9 & 9.9 & 19.8 \\
Civil/Structural Engineer & 2.2 & 11.0 & 13.2 \\
Quantity Surveyor & 8.8 & 12.1 & 20.9 \\
Surveyor & 1.1 & 3.3 & 4.4 \\
Services Engineer & 0 & 1.1 & 1.1 \\
Others & 9.9 & 5.5 & 15.4 \\
\hline Highest qualification obtained & & & \\
OND & 2.2 & 2.2 & 4.4 \\
HND/BSc. & 29.7 & 28.6 & 58.2 \\
PGD & 0 & 4.4 & 4.4 \\
MSc. & 9.9 & 23.1 & 33.0 \\
\hline Respondent's years of & & & \\
experience & 14.3 & 8.8 & 23.1 \\
Less than 5 years & 14.3 & 30.8 & 45.1 \\
6-10 years & 5.5 & 12.1 & 17.6 \\
11-15 years & 0 & 4.4 & 4.4 \\
16-20 years & 7.7 & 2.2 & 9.9 \\
More than 20 years & 41.8 & 58.2 & 100 \\
Overall & & & \\
\hline
\end{tabular}

The survey results were compared with the results of data collected via interviews. The interviewees were 4 experts who were purposively selected because of their long years of experience in the Nigerian construction industry. The experts represent a crosssection of contractors and consultants. The combination of data collection methods (i.e. questionnaire and interviews) provides better understanding of the research problem [20]. As shown in Table 2 all the interviewees were of management cadre and with ample hands-on experience in handling construction projects - this again indicates the authenticity of their views. 
Table 2: Profile of the interviewees

\begin{tabular}{lcllc}
\hline Group & No. & \multicolumn{1}{c}{ Position } & \multicolumn{1}{c}{ Organisation } & Years of Experience \\
\hline Contractor & A & Contract Manager & Multinational & 35 \\
& B & Project Manager & Local & 12 \\
Consultant & C & Assistant Director & State government & 33 \\
& D & Junior Partner & Private consulting & 13 \\
\hline
\end{tabular}

Table 3: Critical causes of conflicts

\begin{tabular}{lcccccc}
\hline \multirow{2}{*}{ Causes of conflicts } & \multicolumn{2}{c}{ Contractor } & \multicolumn{2}{c}{ Consultant } & \multicolumn{2}{c}{ Overall } \\
& Mean & Rank & Mean & Rank & Mean & Rank \\
\hline Poor financial projections on the client's side & 4.25 & 2 & 4.24 & 1 & 4.24 & 1 \\
Lack of funds & 4.21 & 3 & 4.03 & 2 & 4.13 & 2 \\
Poor public relationship between the project people and the & 4.40 & 1 & 3.76 & 9 & 4.13 & 2 \\
public & & & & & & \\
Change of scope of works due client requirement instability & 4.21 & 3 & 3.97 & 4 & 4.11 & 4 \\
Cheap design hired instead of quality & 4.04 & 8 & 4.03 & 2 & 4.03 & 5 \\
\hline
\end{tabular}

Table 4: Least ranked causes of conflicts

\begin{tabular}{lcccccc}
\hline \multirow{2}{*}{ Causes of conflicts } & \multicolumn{2}{c}{ Contractor } & \multicolumn{2}{c}{ Consultant } & \multicolumn{3}{c}{ Overall } \\
& Mean & Rank & Mean & Rank & Mean & Rank \\
\hline Wrong interpretation of site investigation & 3.00 & 63 & 2.92 & 56 & 2.97 & 61 \\
Tendency of contractor claiming high prices & 2.77 & 64 & 3.21 & 46 & 2.96 & 62 \\
Inexperience of the designer & 3.13 & 60 & 2.76 & 61 & 2.93 & 63 \\
Unsuitable contract type & 3.04 & 61 & 2.76 & 61 & 2.92 & 64 \\
\hline
\end{tabular}

\section{DATA ANALYSIS AND RESULTS}

The results of the survey are presented in Table 3-6. Table 3 and 4 shows the five most and four least important causes of conflicts (based on the rank of each variable). Each of the causes of conflict was ranked in the order of importance based on its mean scores. The scale intervals are interpreted as follows: (i) 'not important' (mean score $\geq 1.0$ );(ii) 'fairly important' ( $1.01 \geq$ mean score $\geq 2.0$ ); (iii) 'important' ( $2.01 \geq$ mean score $\geq 3.0$ ); (iv) 'very important' (3.01 $\geq$ mean score $\geq 4.0$ ); and (v) 'extremely important' (mean score $\geq 4.01$ ). In Table 5 , significant difference in the perception of respondents (i.e. contractors and consultants was tested using independent sample ttests. The comments raised by the interviewees were reported and compared with the results of the survey here. Finally, the result of Kruskal-Wallis test is presented in Table 6.

\subsection{Causes of Conflicts}

Based on the cut-off value (i.e. mean score is higher than 4.01) set out in previous section, five perceived variables have been agreed by the respondents as critical causes of conflicts in the Nigerian construction industry. The five critical causes presented in Table 3 are: Poor financial projections on the client's side, Lack of funds, Poor public relationship between the project people and the public, Change of scope of works due to client requirement instability, and Cheap design hired instead of quality with corresponding mean score values of $4.24,4.13,4.13,4.11$, and 4.03 respectively.

In contrast, the overall mean score values of the four causes of conflicts shown in Table 4, have been found to fall between 3.0 and 2.0, this results indicate that they are important in the Nigerian construction industry. Although, these causes have the least mean scores, they are still considered important problems. The causes with the least mean scores are:

- Wrong interpretation of site investigation (Mean $=2.97$, Rank 61)

- Tendency of contractor claiming high prices (Mean $=2.96$, Rank 62)

- Inexperience of the designer (Mean $=2.93$, Rank 63)

- Unsuitable contract type $($ Mean $=2.92$, Rank 64) 
Table 5: Mann Whitney test results on significant causes of conflicts

\begin{tabular}{lcccc}
\hline \multirow{2}{*}{ Causes of conflicts } & \multicolumn{2}{c}{ Overall } & \multicolumn{2}{c}{ Mann-Whitney } \\
& Mean & Rank & U & Sig. \\
\hline Poor financial projections on the client's side & 4.24 & 1 & 937.50 & 0.55 \\
Lack of funds & 4.13 & 2 & 942.50 & 0.58 \\
Poor public relationship between the project people and the public & 4.13 & 2 & 880.50 & 0.28 \\
Change of scope of works due client requirement instability & 4.11 & 4 & 849.50 & 0.18 \\
Cheap design hired instead of quality & 4.03 & 5 & 905.50 & 0.39 \\
\hline
\end{tabular}

Table 6: Kruskal-Wallis test results

\begin{tabular}{llllll}
\hline \multirow{2}{*}{ Rank } & \multirow{2}{*}{ Causes of conflict } & \multicolumn{3}{c}{ Kruskal-Wallis ( $p$-value) } \\
& & Mean & 1 & 2 & 3 \\
\hline 1 & Poor financial projections on the client's side & 4.24 & 0.01 & 0.02 & 0.43 \\
2 & Lack of funds & 4.13 & 0.37 & 0.01 & 0.61 \\
3 & Poor public relationship between the project people and the public & 4.13 & 0.07 & 0.47 & 0.04 \\
4 & Change of scope of works due client requirement instability & 4.11 & 0.04 & 0.96 & 0.05 \\
5 & Cheap design hired instead of quality & 4.03 & 0.06 & 0.74 & 0.22 \\
Notes: 1 -Educational training; 2- Highest educational qualification; 3-Years of experience & & & \\
\hline
\end{tabular}

\subsection{Non Parametric test}

A test for normality of data was performed before selecting test for comparing the mean scores of the different classes of respondents. The results of Kolmogorov-Smirnov and Shapiro-Wilk tests were significant at $95 \%$ level of significance (see Appendix $1)$; this suggests that the distribution significantly deviates from a normal distribution. Therefore, a combination of Mann-Whitney $U$ and Kruskal-Wallis test was performed to detect the difference in significant causes of conflicts based on the perception of respondents.

\subsubsection{Mann-Whitney U test}

According to Table 5, it is evident that all the p-values are higher than 0.05 , it can be deduced that for the critical causes of conflicts, there is no significant differences in the perception of consultants and contractors. Thus, the Mann-Whitney $U$ test results supports that the seven factors are significant as per criteria from previous section.

\subsubsection{Kruskal-Wallis test}

According to Table 6, it can be seen that the mean score for all the critical factors were less than 0.05 for some variables. These shows that the means scores differ significantly for some factors across different population categories; except for "Cheap design hired instead of quality " which showed no differences for all the groups. The results from the Mann Whitney test clearly shows that the organisational group's mean scores do not differ significantly (all $p>0.05$ ) with respect to all six factors. However, the Kruskal-Wallis test was also performed for all demographic characteristics of the respondents. This showed that there were differences amongst the groups except for "Cheap design hired instead of quality" which showed no differences. Therefore, it is reasonable to conclude that the five causes of conflicts are critical. Although, the other 59 survey causes could also contribute to conflicts in construction projects. This study fails to recognise those causes as critical ones; this is due to the mean score of the causes.

\subsection{Convergence and divergence of questionnaire and interview findings}

In order to gain deeper insights into the study's problem; the findings from the survey were compared with the findings from the interview. As shown in Table 5, the contractors and consultants respondents agreed that there was no significant difference in the means scores of the critical causes of conflicts in construction projects. Most of the interviewees acknowledged finance as a source of conflicts in construction projects. The themes that emerged from the interviewees generally point to the factors identified from the questionnaire survey. The contract manager observed that for government funded projects, "most of the designs for dam projects were re-designed at construction phase and this could 
increase cost of project by about 300\%". This leads to conflicts amongst project teams which results in delays and increased cost. However, the project manager in the local contracting firm mentioned that "cases of inter-statutory authority clashes occur". This primarily results from overlapping statutory duties. The professionals representing the client (i.e. assistant director and junior partner) mentioned that contractors often exploited gaps in project documents to the detriment of the project.

\section{CONCLUSION}

Conflict is commonplace in the construction sector. This is even more severe in environments without institutional frameworks for tendering and executing projects. Drawing on a mixed research method five critical causes of conflict were signposted out of the 64 causes identified. A finding which will enable decision makers like project managers manage conflict better since the ability to manage conflict depends on how well they can recognize remote causes of conflict. There would be need for future studies to deconstruct conflict into Positive and Negative conflict since it is evident that positive conflict is key to achieving improved outcomes.

\section{REFERENCES}

[1] Acharya, N. K., Lee, Y. D. and Im, H. M. "Conflicting factors in construction projects: Korean perspective," Eng. Constr. Archit. Manag., vol. 13, no. 6, pp. 543-566, 2006.

[2] Fenn, P. Lowe, D. and Speck, C. "Conflict and dispute in construction," Constr. Manag. Econ., vol. 15, no. 6, pp. 513-518, 1997.

[3] Jaffar, N., Abdul Tharim, A. H. and Shuib, M. N. "Factors of conflict in construction industry: A literature review," in Procedia Engineering, 2011, vol. 20, pp. 193-202.

[4] Kumaraswamy, M. M. "Conflicts, claims and disputes in construction," Eng. Constr. Archit. Manag., vol. 4, no. 2, pp. 95-111, 1997.

[5] Liu, J. Y. C., Chen, H.-G., Chen, C. C. and Sheu, T. S. "Relationships among interpersonal conflict, requirements uncertainty, and software project performance," Int. J. Proj. Manag., vol. 29, no. 5, pp. 547-556, 2011.

[6] Love, P. E. D. and Edwards, D. J. "Determinants of rework in building construction projects," Eng. Constr. Archit. Manag., vol. 11, no. 4, pp. 259-274, 2004.

[7] Awakul, P. and Ogunlana, S. 0. "The effect of attitudinal differences on interface conflicts in large scale construction projects: A case study," Constr. Manag. Econ., vol. 20, no. 4, pp. 365-377, 2002.

[8] Kuhn, T. and Poole, M. S. "Do Conflict Management Styles Affect Group Decision Making?," Hum. Commun. Res., vol. 26, no. 4, pp. 558-590, 2000.

[9] Leung, M., Liu, A. M. M. and Ng, S. T. "Is there a relationship between construction conflicts and participants' satisfaction?," Eng. Constr. Archit. Manag., vol. 12, no. 2, pp. 149-167, 2005.

[10] Mahalingam, A. and Levitt, R. E. "Institutional theory as a framework for analyzing conflicts on global projects," J. Constr. Eng. Manag., vol. 133, no. 7, pp. 517-528, 2007.

[11] Dada, M. O. "Analysis of Conflict Centers in Projects Procured with Traditional and Integrated Methods in Nigeria," J. Eng. Proj. Prod. Manag., vol. 2, no. 2, pp. 66-77, 2012.

[12] Consoli, G. G. S. "Conflict and managing consortia in private prison projects in Australia - Private prison operator responses," Int. J. Proj. Manag., vol. 24, no. 1, pp. 75-82, 2006.

[13] Kumaraswamy, M. M. "Consequences of construction conflict: A Hong Kong perspective," J. Manag. Eng., vol. 14, no. 3, pp. 66-74, 1998.

[14] Oshodi, S. O. and Ejohwomu, O. A. "Causes of conflicts in construction projects in Nigeria: Consultant's and Contractor's perspectives," in Proceedings of the CIB W107 2014 International Conference, 2014, pp. 325-333.

[15] Ntiyakunze, S. K. “Conflicts in Building Projects in Tanzania:Analysis of Causes and Management Approaches," Department of Real Estate and Construction Management, Royal Institute of Technology, Stockholm, Sweden, 2011.

[16] Tjosvold, D. "Cooperative and Competitive Goal Approach to Conflict: Accomplishments and Challenges," Appl. Psychol. An Int. Rev., vol. 47, no. 3, pp. 285-313, 1998.

[17] Lester, A. "Project Management, Planning and Control," Project Management, Planning and Control, vol. 5th. Butterworth-Heinemann, Burlington, 2007.

[18] Kerzner, H.Project management: A systems approach to planning, scheduling, and controlling, vol. 7th. NewYork: John Wiley \& Sons, Inc., 2001.

[19] Williamson, 0. E. "Transaction-cost economics: the governance of contractual relations," J. law Econ., pp. 233-261, 1979.

[20] Creswell, J. W. Research design: Qualitative, quantitative, and mixed methods approaches, vol. 4th. Sage publications, 2013.

[21] Ejohwomu, 0. A. and Oshodi, S. O. "Built 
Environment Research Outputs on Sustainable Developments in Nigeria: A Call for Paradigm Shift," in 3rd International Conference on Infrastructure Development in Africa, 2014, pp. 487-492.
[22] Akintoye, A. "Analysis of factors influencing project cost estimating practice," Constr. Manag. Econ., vol. 18, no. 1, pp. 77-89, 2000.

APPENDIX: Test of normality

\begin{tabular}{|c|c|c|c|c|c|c|c|}
\hline Critical and Least ranked causes of conflicts & & Statistic & $\mathrm{df}$ & Sig. & Statistic & $\mathrm{df}$ & Sig. \\
\hline \multirow[t]{2}{*}{ Poor financial projections on the client's side } & Contractor & .265 & 53 & .000 & .778 & 53 & .000 \\
\hline & Consultant & .335 & 38 & .000 & .726 & 38 & .000 \\
\hline \multirow[t]{2}{*}{ Lack of funds } & Contractor & .296 & 53 & .000 & .740 & 53 & .000 \\
\hline & Consultant & .253 & 38 & .000 & .785 & 38 & .000 \\
\hline \multirow{2}{*}{$\begin{array}{l}\text { Poor public relationship between the project people and the } \\
\text { public }\end{array}$} & Contractor & .424 & 53 & .000 & .326 & 53 & .000 \\
\hline & Consultant & .281 & 38 & .000 & .864 & 38 & .000 \\
\hline \multirow[t]{2}{*}{ Change of scope of works due client requirement instability } & Contractor & .262 & 53 & .000 & .788 & 53 & .000 \\
\hline & Consultant & .211 & 38 & .000 & .850 & 38 & .000 \\
\hline \multirow[t]{2}{*}{ Cheap design hired instead of quality } & Contractor & .238 & 53 & .000 & .840 & 53 & .000 \\
\hline & Consultant & .299 & 38 & .000 & .750 & 38 & .000 \\
\hline \multirow[t]{2}{*}{ Wrong interpretation of site investigation } & Contractor & .216 & 53 & .000 & .887 & 53 & .000 \\
\hline & Consultant & .243 & 38 & .000 & .862 & 38 & .000 \\
\hline \multirow[t]{2}{*}{ Tendency of contractor claiming high prices } & Contractor & .214 & 53 & .000 & .882 & 53 & .000 \\
\hline & Consultant & .239 & 38 & .000 & .895 & 38 & .002 \\
\hline \multirow[t]{2}{*}{ Inexperience of the designer } & Contractor & .190 & 53 & .000 & .901 & 53 & .000 \\
\hline & Consultant & .230 & 38 & .000 & .897 & 38 & .002 \\
\hline \multirow[t]{2}{*}{ Unsuitable contract type } & Contractor & .222 & 53 & .000 & .908 & 53 & .001 \\
\hline & Consultant & .196 & 38 & .001 & .884 & 38 & .001 \\
\hline
\end{tabular}

